\title{
Anonymous Witnesses in England and Wales: Charting a Course from Strasbourg?
}

\author{
Jonathan Doak* and Rebecca Huxley-Binns ${ }^{\dagger}$
}

\begin{abstract}
The use of anonymous testimony in England and Wales has recently been the subject of a number of high-profile appellate decisions and legislative intervention. As the law currently stands, it is permissible for the criminal courts to receive such testimony, subject to certain safeguards. This article evaluates the position against the threshold for anonymous evidence laid down by the European Court of Human Rights. It is argued that such evidence is too readily admissible under the current legislative framework. As such, the rules regulating the use of anonymous testimony should be amended so that they comply fully with the fair trial rights of the accused.
\end{abstract}

Keywords Anonymity; Witnesses; Intimidation; Fair trial; Due process

Recent years have witnessed considerably greater attention being paid to the problems posed by witness intimidation. ${ }^{1}$ Many jurisdictions have rolled out witness protection programmes and introduced a range of measures to protect witnesses when giving evidence in court. ${ }^{2}$ Some, including England and Wales, make provision for fearful witnesses to give their testimony in hearsay form, thus avoiding the need to come to court altogether. ${ }^{3}$ Occasionally, particularly in cases involving young people and sexual offences, identities of victims and witnesses may be withheld from the public record and restrictions may be placed on media

* Reader in Law, Nottingham Law School, Nottingham Trent University; e-mail: jonathan.doak@ntu.ac.uk.

† Senior Lecturer in Law, Nottingham Law School, Nottingham Trent University; e-mail: rebecca.huxleybinns@ntu.ac.uk.

1 Until recently, there was little empirical evidence as to how widespread witness intimidation may be. However, in 2006, the Home Office noted that the number of cases for perverting the course of justice (which includes witness intimidation) rose by over 30 per cent between 2000 and 2005 (Home Office, Working with Intimidated Witnesses (2006)). Drawing on the findings of the 1998 British Crime Survey, Tarling et al. concluded that intimidation occurs in just under 10 per cent of reported crime and 20 per cent of unreported crime: R. Tarling, L. Dowds and T. Budd, Victim and Witness Intimidation: Findings from the British Crime Survey (Home Office: London, 2001). Angle et al.'s 2002 survey found that a quarter of all witnesses felt intimidated by an individual, which was actually higher than the 21 per cent who reported feeling intimidated by the process of giving evidence: $H$. Angle, S. Malam and C. Carey, Witness Satisfaction: Findings from the Witness Satisfaction Survey 2002 (Home Office: London, 2003).

2 In England and Wales, a range of special measures, including the use of screens and televised testimony are available in certain circumstances under Pt II of the Youth Justice and Criminal Evidence Act 1999.

3 See Criminal Justice Act 2003, s. 116(2)(e) and the recent Court of Appeal decision in $R$ v Horncastle [2009] EWCA Crim 964. 
reporting. ${ }^{4}$ Whilst many of these measures are contentious in their own right, none has caused quite a stir as the receipt of anonymous evidence where the identity of an opposing witness is withheld from the defence.

In the view of some observers, the granting of anonymity to prosecution witnesses is nothing short of an affront to the principle of open justice. The right of the accused to 'confront' opposing witnesses is said to incorporate dignitarian, symbolic and instrumental purposes, including assisting in the ascertainment of truth, ensuring greater openness, and offering the defendant a more effective and fairer means of challenging the prosecution's case. ${ }^{5}$ The dangers of anonymous evidence are said to include secrecy, ${ }^{6}$ the inability of the accused to challenge opposing witnesses, ${ }^{7}$ a decline in public confidence, ${ }^{8}$ a shift toward 'antidemocratic' values; ${ }^{9}$ and the risk of a 'slippery slope' toward further curtailment of fair trial rights. ${ }^{10}$ Such disquiet is unsurprising; the principle of orality, which lies at the heart of the common law trial, requires that evidence is given live in court by the witness in person. However, by the same token, it should be borne in mind that, with the recent rise in serious organised and gang-related crime, many witnesses will be reluctant to testify unless they are provided with a reassurance that their identity will be concealed from the accused. There is a clear policy incentive for protecting the identities of informers in such cases; ${ }^{11}$ and anonymity is one possible means of achieving that. Moreover, a failure to offer a sufficient level of protection to witnesses at risk of intimidation could, in certain cases, constitute a breach of their rights under Articles 2, 3 and 8 of the European Convention on Human Rights, as well as a plethora of international soft-law standards. ${ }^{12}$

The juxtaposition between these two sets of objectives has recently been catapulted to the forefront of political and legal debates in England and Wales, following the decision of the House of Lords in $R \mathrm{v}$ Davis and Others $^{13}$ in April 2008. In response, the government rushed through emergency legislation in the form of the Criminal Evidence (Witness

4 See further A. Gillespie and V. Bettinson, 'Preventing Secondary Victimisation through Anonymity' (2007) 70 MLR 114.

5 See e.g. G. Marcus, 'Secret Witnesses' [1990] PL 207; S. Enright, 'The Anonymous Witness' (1996) 146 NLJ 1032; R. Friedman, 'Face to Face: Rediscovering the Right to Confront Prosecution Witnesses' (2004) 8 E \& P 1; W. O'Brian, 'The Right of Confrontation: US and European Perspectives' (2005) 121 LQR 481.

6 See e.g. R. Costigan and P. Thomas, 'Anonymous Witnesses' (2000) 51 NILQ 326; S. Burns, 'Blind Shots at a Hidden Target' (2008) 158 NLJ 1091; D. Lusty, 'Anonymous Accusers: An Historical and Comparative Analysis of Secret Witnesses in Criminal Trials' (2002) 24 Sydney Law Review 361; Justice, Secret Evidence (Justice: London, 2009).

7 See e.g. O'Brian, above n. 5; Lusty, above n. 6; Burns, above n. 6.

8 Costigan and Thomas, above n. 6.

9 Ibid.

10 See M. Swift QC, 'Witness anonymity: a slippery slope', The Times, 27 June 2008. See also Lusty, above n. 6.

11 See comments of Edmund-Davies LJ in Dv NSPCC [1978] AC 171 at 176.

12 See J. Doak, Victims' Rights, Human Rights and Criminal Justice: Reconceiving the Role of Third Parties (Hart: Oxford, 2008) ch. 2.

13 [2008] 1 AC 1128. 
Anonymity) Act 2008, and subsequently proposed a longer-term solution under the auspices of the Coroners and Justice Bill 2009. This article considers these developments against the backdrop of the European Convention on Human Rights alongside the pressing public policy objective of encouraging intimidated witnesses to testify. We contend that the law as it stands still falls short of the Strasbourg requirementnamely that reliance on the testimony of anonymous witnesses should be 'strictly necessary' and should not be the 'sole or decisive' basis for a conviction. If intimidated witnesses are to be encouraged to testify, it is necessary to consider other legal and policy options that will carry less drastic an impact upon the fairness of the trial.

\section{Anonymity and the ECHR}

The main Convention provision governing the use of anonymous testimony is Article 6(3)(d), which guarantees the accused the right 'to examine or have examined witnesses against him and to obtain the attendance and examination of witnesses on his behalf under the same conditions as witnesses against him'. Although the provision is sometimes said to enshrine a 'right to confrontation', ${ }^{14}$ the wording of the Convention itself gives us little guidance as to whether physical confrontation is an essential element of Article 6(3)(d). Certainly, the Article does not purport to mirror the so-called 'confrontation principle' enshrined in the Sixth Amendment of the US Constitution, ${ }^{15}$ and there is considerable ambiguity in its scope compared with its American counterpart. This can, perhaps, be attributable to its comparative juvenescence, as well as the fact that it embodies a standard that must be capable of applying across jurisdictions with quite different legal cultures without causing undue disquiet. For this reason, the European Court of Human Rights has often shied away from being over-prescriptive concerning specific modalities of criminal procedure and evidence. Breaches of the right to a fair trial are unlikely to be found on the basis of evidential or procedural rules, with the court expressing a clear preference in favour of examining the trial process as a whole in order to ascertain whether the fundamental requirements of fairness have been observed. ${ }^{16}$

The European Court of Human Rights is first and foremost concerned with monitoring the 47 Member States of the Council of Europe to ensure they act in accordance with the Convention. The transcultural

14 S. Maffei, The European Right to Confrontation in Criminal Proceedings (Europa: Groningen, 2006) 61; J. Swergold, "Taking "Blind Shots at a Hidden Target": Witness Anonymity in the United Kingdom' (2009) 30(2) Boston College International and Comparative Law Review 471 at 478.

15 The scope of the latter is broad, and it embodies a number of different demands: that testimony should be given under oath, subjected to cross-examination, given in the presence of the accused and in the presence of the trier of fact. For a comparative analysis, see O'Brian, above n. 5.

16 See Barbera, Messegue and Jabardo v Spain (1988) 11 EHRR 360 at [68]; Doorson v Netherlands (1996) 22 EHRR 330 at [67], Van Mechelen v Netherlands (1997) 25 EHRR 647 at [50]; PS v Germany (2001) 36 EHRR 1139 at [19]; Lucà v Italy (2003) 36 EHRR 46 at [38]. 
nature of this role, coupled with the fact that the court does not actually have the power to quash convictions, means that the court is unlikely to become embroiled in laying down specific guidelines on aspects of criminal procedure and evidence. It is thus unsurprising that the court has been reluctant to define the precise parameters of Article 6(3)(d), a position that has been exacerbated by a lack of clarity as what to what actually constitutes 'anonymous' testimony. ${ }^{17}$ The term may cover unidentified witnesses who have provided information to the police incognito, or alternatively may include witnesses whose identity is known to the Crown and the court, but whose identity will have been withheld from both the defendant and his counsel. In addition, the witness's identity may be known by all parties involved, but withheld from the general public through the imposition of reporting restrictions. As we shall see, the Strasbourg Court has occasionally failed to delineate which sets of principles ought to apply to which types of 'anonymous' witness. Notwithstanding, it remains true that the task of ascertaining core principles from the court's jurisprudence is far from straightforward. It is, perhaps, little wonder that both the appellants and respondents in Davis felt that the weight of the Convention case law fell in their favour.

The Strasbourg Court has reiterated on a number of occasions that evidence should be given in the presence of the accused at a public hearing with a view to adversarial argument. ${ }^{18}$ However, there are exceptions to this principle, and the ambiguity has arisen from the precise circumstances as to when such departures should be regarded as compatible with the rights of the defence. In much of its earlier case law, the court seemed to place an overriding emphasis on the need for witnesses to at least attend court and be available to have their evidence challenged by the accused. ${ }^{19}$ In Windisch v Austria, ${ }^{20}$ the court appeared to doubt the validity of anonymous evidence at all:

[T] he Court notes that the Convention does not preclude reliance, at the investigation stage, on sources such as anonymous informants. However, the subsequent use of their statements by the trial court to found a conviction is another matter. The right to a fair administration of justice holds so prominent a place in a democratic society that it cannot be sacrificed. ${ }^{21}$

However, in more recent times the court has apparently softened its stance, perhaps anxious to be seen to be responsive to the growing problem of witness intimidation. In an oft-cited passage in Doorson $\mathrm{v}$ Netherlands, ${ }^{22}$ the court stated that:

17 See D. Ormerod, 'Evidence: Witnesses Anonymity' [2007] Crim LR 70.

18 See e.g. Kostovski v Netherlands (1989) 12 EHRR 434; Unterpinger v Austria (1986) 13 EHRR 175; Riepan v Austria (App. No. 35115/97, 14 November 2000); AM v Italy (App No. 37019/97, 14 December 2001).

19 See e.g. Unterpinger v Austria (1986) 13 EHRR 175; Delta v France (1990) 16 EHRR 574; Kostovski v Netherlands (1989) 12 EHRR 434; Ludi v Switzerland (1992) 15 EHRR 173; Saidi v France (1993) 17 EHRR 251.

20 Windisch v Austria (1991) 13 EHRR 281.

21 Ibid. at [30].

22 Doorson v Netherlands (1996) 23 EHRR 330. 
It is true that Article 6 does not explicitly require the interests of witnesses in general, and those of victims called upon to testify in particular, to be taken into consideration. However, their life, liberty or security of person may be at stake, as may interests coming generally within the ambit of Article 8 of the Convention ... Contracting States should organise their criminal proceedings in such a way that those interests are not unjustifiably imperilled. Against this background, principles of fair trial also require that in appropriate cases the interests of the defence are balanced against those of witnesses or victims called upon to testify. ${ }^{23}$

It was thus held that the court should undertake an interest-balancing exercise since the accused's right to a fair trial may come into conflict with the rights of victims and witnesses. Positive obligations concerning the right to life, the right to be free from inhuman and degrading treatment, and the right to privacy will frequently come into play in cases where witnesses are considered to be at risk from reprisals. This case underlines an apparent departure from the court's traditional approach to focusing solely on the rights of the accused towards taking into account newly emergent rights of victims, witnesses and the broader community. ${ }^{24}$ Thus in Van Mechelen $\mathrm{v}$ Netherlands, ${ }^{25}$ it was held that 'the use of statements made by anonymous witnesses is not under all circumstances incompatible with the Convention' ${ }^{26}$ However, the task of discerning any set of overriding principles as to when anonymous testimony should be admitted is somewhat difficult. It might be said that there are three fundamental safeguards to have emerged from the case law to date: anonymous testimony should only be received if it is 'strictly necessary'; anonymous testimony should not form the 'sole or decisive' basis for any conviction; and, where it is used, sufficient counterbalancing measures must be in place for the defence.

\section{(a) Anonymous testimony should only be received if it is 'strictly necessary'}

It is clear that anonymity should only ever be used as a special measure of last resort. ${ }^{27}$ In Van Mechelen, 11 undercover police officers gave evidence anonymously in the judge's chambers. Testimony was relayed to the accused and his counsel via a sound link, and the judge himself conducted the cross-examination. In the view of the court, the 'extreme limitations on the right of the accused to have the evidence against them given in their presence' could not be justified. ${ }^{28}$ It was held that police officers, as part of their public duty, should be prepared to give evidence before defendants in court. Although domestic courts should be prepared to undertake a comprehensive assessment of the threat posed to witnesses, here adequate reasons had not been given as to why such 'extreme limitations' on the rights of the accused were necessary. In an oft-cited passage, the court held that 'any measures restricting the rights

23 Above n. 22 at [70].

24 See further Doak, above n. 12.

25 Van Mechelen v Netherlands (1998) 25 EHRR 657.

26 Ibid. at [52].

27 See $R$ v Mayers [2008] EWCA Crim 1418 at [8].

28 Van Mechelen $\mathrm{v}$ Netherlands (1998) 25 EHRR 657 at [60]. 
of the defence should be strictly necessary. If a less restrictive measure can suffice, then that measure should be applied' ${ }^{29}$

Although the European Court of Human Rights has not to date provided a definitive answer as to what anonymity orders should be strictly necessary for, it is clear that they should be confined to the most serious of cases. In all cases where the court has held anonymity to be justifiable under Article 6, witnesses had been subjected to, or had reasonable grounds to fear that they would be subject to, some form of intimidation or reprisal. Where a genuine threat to life or physical integrity has been made, Article 2 or 3 will be triggered. In such circumstances, state bodies (including the courts) are under a positive obligation to take preventative operational measures to protect an individual whose life is at risk from the criminal acts of another individual. ${ }^{30}$ Thus where protection of identity is deemed necessary to protect the witness, then domestic courts are under an obligation to do so. ${ }^{31}$ It is clear that it is not a requirement that actual threats towards the witness have been made, yet by the same token the witness's subjective fear of reprisal is insufficient in itself to justify anonymity. In more recent cases, the court has placed a particular emphasis upon the veracity of the witness's fear and whether it was based on reasonable grounds. In Visser $\mathrm{v}$ Netherlands, ${ }^{32}$ for example, the court found that the domestic court had improperly issued an anonymity order on the grounds that the applicant's co-accused had a history of violence; there was no evidence that the individual in question intended to harm the applicant.

In certain cases involving child victim-witnesses, the concept of necessity extends beyond physical integrity. Restrictions can be placed upon the rights of the defence to safeguard the privacy interests of the child. In $S N$ v Sweden, ${ }^{33}$ the court highlighted that special considerations needed to be taken into account in cases involving sexual offences against children:

The Court has had regard to the special features of criminal proceedings concerning sexual offences. Such proceedings are often conceived of as an ordeal by the victim, in particular when the latter is unwillingly confronted with the defendant. These features are even more prominent in a case involving a minor. In the assessment of the question whether or not in such proceedings an accused received a fair trial, account must be taken of the right to respect for the private life of the perceived victim. Therefore, the Court accepts that in criminal proceedings concerning sexual abuse certain measures may be taken for the purpose of protecting the victim, provided

29 Above n. 28 at [59].

30 In relation to Art. 2, see Osman v United Kingdom [1999] EHRLR 228. A similar positive obligation exists in relation to Art. 3: A v United Kingdom (1999) 27 EHRR 611.

31 See the recent joined cases before the House of Lords: Van Colle v Chief Constable of Hertfordshire; Smith v Chief Constable of Sussex [2009] 1 AC 225. Although the House of Lords acknowledged the duty of the police to protect fearful witnesses, the specific facts of these cases meant that there had been no breach of Art. 2 under the test laid down by the Strasbourg Court in Osman v United Kingdom [1999] EHRLR 228 at [115]-[116].

32 App. No. 26668/95, 14 February 2002.

33 (2004) 39 EHRR 13. 
that such measures can be reconciled with an adequate and effective exercise of the rights of the defence. ${ }^{34}$

In the instant case, although defence counsel was not present when the child was interviewed by police officers, the court was of the view that the defence had been afforded adequate opportunity to challenge the victim's credibility in the course of the trial. Indeed, counsel for the accused had voluntarily opted to forego his right to attend one of the pre-recorded interviews with the child complainant, where he would have had the opportunity to put questions through an intermediary. The domestic court had thus taken appropriate steps to balance the rights of the complainant alongside the fair trial rights of the defence, with the result that no violation of Article 6. By contrast, the case of $P S$ $\mathrm{v}$ Germany $^{35}$ concerned the admissibility of out-of-court statements made by an alleged child victim of a sexual offence. While the court heard corroborating evidence from the child's mother and a police officer, the defence did not have the opportunity to question the child. On the facts of the case, the court did not feel that the refusal to hear the witness was necessary in the circumstances of the case and thus Article 6 had been violated.

It should be underlined, however, that $P S$ and $S N$ did not involve anonymous witnesses; the identities of the accusers were all known to the defence. The court was satisfied that there was no requirement under Article 6 for the complainants to be questioned directly by the defence in court. As argued below, care should be taken to distinguish these cases from many of the other leading authorities including Doorson, Kostovski and Van Mechelen, where the identities of the accusers were withheld from the defence in circumstances where their credibility was in issue. In these types of cases, we can assume that the 'necessity' principle should be applied in full measure.

\section{(b) Anonymous testimony should not form the 'sole or decisive' basis for any conviction}

The idea that convictions should not be based on anonymous evidence alone was first advanced by the European Court of Human Rights in its first major decision on anonymity, Kostovski v Netherlands. ${ }^{36}$ The convictions of two men for armed robbery had been based on statements given to the police by two anonymous witnesses. Both witnesses feared that they would be subject to reprisal attacks if their identity were made known. Although they had been interrogated at length by the police, and one had also been questioned by the examining magistrate, the defence were unable to question them. The court subsequently held that Article 6 had been breached.

The facts of Doorson were similar, but the court found sufficient grounds to distinguish it from Kostovski and found no violation. Doorson

34 Above n. 33 at [47]. See also Baegen v Netherlands (App. No. 16696/90, 26 October 1995); Finkensieper v Netherlands (App No. 19525/92, 17 May 1995).

35 PS v Germany (2003) 36 EHRR 61.

36 Kostovski v Netherlands (1989) 12 EHRR 434. 
concerned drug trafficking, and there was information on police files which suggested that, if the witnesses' identities were made known to the applicant, there was a real risk of the threats being carried out (rather than merely made). The witnesses in Doorson were granted anonymity like those in Kostovski, but defence counsel was permitted to attend the magistrates' hearing and put questions to them through the magistrates. Two witnesses gave anonymous evidence before the investigating judge. The accused was not present, and his counsel was not permitted to question the witnesses extensively. The accused contended that this practice constituted a breach of Articles 6(1) and 6(3)(d), insofar as he had not been present when this evidence was given, nor had he had the opportunity properly to question the witnesses. The Commission expressed the opinion that there had been no violation of the Convention (by 15 votes to 12 ), and this opinion was followed by the European Court of Human Rights (by 7 votes to 2). The court appeared to place a particular emphasis on the fact that the conviction in this case was not based 'solely or to a decisive extent' on the anonymous evidence. $^{37}$

In Visser $\mathrm{v}$ Netherlands, ${ }^{38}$ a witness had been granted anonymity when he agreed to give evidence against the defendant, who had a reputation for violence in the community. The defendant was convicted, and complained that he had not been afforded a fair trial since neither he nor his counsel had been given the opportunity to see the anonymous witness, and had thus been unable to observe his demeanour under cross-examination. However, more than five years had passed since the witness first gave a statement to the police, while the applicant's coaccused, whom the witness was purported to fear, had been released from prison in 1988. The court found that there was no cause for anyone to believe that they might be targeted by him, and went on to hold that, since the conviction was based primarily on the evidence of the anonymous witness, the principles set out in Doorson had been contravened in this specific case. Similar reasoning was applied in the more recent case of Krasniki v Czech Republic. ${ }^{39}$ Even though the defence lawyer had been present during the taking of the pre-trial statements, and had the chance to put questions to the witnesses, the court found a violation since the conviction had nonetheless been based at least to a decisive extent on the anonymous evidence.

In spite of the similarity of language used in the case law, it is worth underlining that the terms are not synonymous and the court has not always been consistent in delineating the distinction between them. ${ }^{40} \mathrm{In}$ the past, the court has stated that a conviction should not be based on

37 Above n. 36 at [76].

38 Visser v Netherlands (App. No. 26668/95, 14 February 2002).

39 Krasniki v Czech Republic (App. No. 51277/99, 28 February 2006).

40 See also O'Brian, above n. 5 at 494; J. Coster van Voorhout, 'Intelligence as Legal Evidence: Comparative Criminal Research into the Viability of the Proposed Dutch Scheme of Shielded Intelligence Witnesses in England and Wales, and Legislative Compliance with Article 6(3)(d) ECHR' (2006) 2(2) Utrecht Law Review 119 at 142. 
anonymous testimony 'solely', ${ }^{41}$ 'to a decisive extent', ${ }^{42}$ 'in any respect decisive', ${ }^{43}$ 'solely or decisively', 44 'solely or significantly' ${ }^{45}$, 'mainly' ${ }^{46}$ or even where the evidence simply 'played a part' ${ }^{47}$ Moreover, the task of identifying the specific basis for a conviction is not always a straightforward task, and further confusion arises from the court being prone to rely on its reasoning in past cases concerning out-of-court statements of persons known to the defence in those cases involving anonymous witnesses whose identities are withheld. The decision in Visser provides a useful illustration. The evidence there was entirely anonymous, yet the court drew from its reasoning in other cases such as Saïdi v France ${ }^{48}$ and Asch v Austria, ${ }^{49}$ which concerned out-of-court statements, rather than anonymous evidence. While some of the arguments in each type of case may well be cross-applicable, there is a danger in being too ready to apply reasoning in quite different types of cases. This is particularly true in cases involving children or other vulnerable witnesses. In $S N$ v Sweden, discussed above, the court found no violation in spite of the fact that the out-of-court statements of the child witness were 'virtually the sole evidence' on which the conviction was based. ${ }^{50}$ That decision was clearly dependent on very particular circumstances of the case (i.e. the seriousness of the offence and the age of the child). Such reasoning should not be used to support a broader approach for sanctioning the use of anonymous evidence.

The court took the opportunity to clarify the law in the joined cases of Al-Khawaja and Tahery $\mathrm{v}$ United Kingdom. ${ }^{51}$ For the purposes of this article, it is Tahery's case that is the more pertinent. Witness ' $\mathrm{T}$ ' was known to the defendant, but had informed the court that he was too frightened to give evidence. The prosecution thus sought to rely on an out-of-court hearsay statement as a central plank of their case, and Tahery was duly convicted. The court found a violation of Article 6 on the grounds that there was no realistic way in which the defence would have been able to rebut his account effectively. In such circumstances, the starting point for assessing whether a violation had occurred was laid down in Lucà v Italy: ${ }^{52}$

If the defendant has been given an adequate and proper opportunity to challenge the depositions either when made or at a later stage, their admission in evidence will not in itself contravene Article 6. The corollary of that, however, is that where a conviction is based solely or to a decisive

41 Windisch v Austria (1991) 13 EHRR 281; Saïdi v France (1993) 17 EHRR 251.

42 Kostovski v Netherlands (1989) 12 EHRR 434 at [44]; Delta v France (1990) 16 EHRR 574 at [37]; Asch v Austria (Series A No. 203, 26 April 1991) at [28].

43 Visser v Netherlands (App. No. 26668/95, 14 February 2002) at [46]; Kok v Netherlands (App. No. 43149/98, 4 July 2000).

44 Doorson v Netherlands (1996) 23 EHRR 330 at [76].

45 Sadak v Turkey (2003) 36 EHRR 26 at [65].

46 Isgrò v Italy (App. No. 11339/85, 19 February 1991) at [35]-[37].

47 Lüdi v Switzerland (1993) 15 EHRR 173 at [49].

48 (1991) 15 EHRR 597.

49 (1993) 17 EHRR 251.

50 (2004) 39 EHRR 13 at [52].

51 (2009) 49 EHRR 1.

52 (2001) 36 EHRR 807. 
degree on depositions that have been made by a person whom the accused has had no opportunity to examine or to have examined, whether during the investigation or at the trial, the rights of the defence are restricted to an extent that is incompatible with the guarantees provided by Article $6 .{ }^{53}$

While a departure from these principles may be possible where witnesses had been identified to the defence and where a state of fear had been induced by the defendants, ${ }^{54}$ the position as regards anonymous witnesses at Strasbourg is now relatively clear. A conviction cannot be based solely or to a decisive degree on their evidence if the defence have not had an opportunity to examine them.

(c) Sufficient counterbalancing measures must be in place so as to ensure a fair trial for the defence

The Strasbourg Court has been always consistent in demanding that sufficient steps be taken to counterbalance the additional handicaps suffered by the defence where anonymous witnesses are used. In Van Mechelen the court noted that, where anonymity is granted, 'the defence will be faced with difficulties which criminal proceedings should not normally involve'. ${ }^{55}$ Accordingly, Articles 6(1) and 6(3)(d) required 'that the handicaps under which the defence labours be sufficiently counterbalanced by the procedures followed by the judicial authorities' ${ }^{56}$ Similar dicta can be found in the judgments in Kostovski, ${ }^{57}$ Doorson, ${ }^{58}$ and Visser. ${ }^{59}$

The court has been reticent to offer an exhaustive prescription of what such counterbalancing procedures might involve, but they would appear to include such matters as the provision of sound links, ${ }^{60}$ the opportunity for the trier of fact to see or hear the witness to assess credibility; ${ }^{61}$ or putting in place special arrangements for the defence counsel to question the witness either directly or through the judge/ magistrate ${ }^{62}$ or even a police officer. ${ }^{63}$ However, in the case of Kok v Netherlands, ${ }^{64}$ the court appeared to suggest that the extent of counterbalancing measures needed would ultimately hang on the degree to which the evidence was decisive. In other words, when assessing

53 Above n. 52 at [40].

54 Distinguishing the English case of $R$ v Sellick [2005] 1 WLR 3641.

55 Van Mechelen v Netherlands (1998) 25 EHRR 657 at [54].

56 Ibid. at [52]-[53].

57 (1989) 12 EHRR 434 at [43].

58 (1996) 23 EHRR 330 at [72].

59 App. No. 26668/95, 14 February 2002 at [46].

60 Kok v Netherlands (App. No. 43149/98, 4 July 2000).

61 Isgrò v Italy (App. No. 11339/85, 19 February 1991).

62 See e.g. Delta v France (Series A no. 191-A, 19 December 1990); PS v Germany; Kok v Netherlands (App. No. 43149/98, 4 July 2000); Birtus v Lithuania (App. Nos 47698/99 and 48115/99, 28 March 2002). However, where the judge undertakes all of the questioning, the defence are still disadvantaged to an extent insofar as they are unable to observe the demeanour of the witness: Kostovski v Netherlands (1989) 12 EHRR 434 at [42]; Van Mechelen v Netherlands (1998) 25 EHRR 657 at [51].

63 SN v Sweden (2004) 39 EHRR 13

64 App. No. 43149/98, 4 July 2000. 
whether the procedures followed in the questioning of an anonymous witness had been sufficient to counterbalance the difficulties caused to the defence, due weight had to be given to the extent to which the anonymous testimony had been decisive in convicting the applicant. ${ }^{65}$

Despite the court's opinion in Doorson that there would be no compensatory measures that would allow deviation from the sole/decisive requirement, ${ }^{66}$ there has been some suggestion that the above-noted sole/decisive criterion may be dispensed with altogether providing sufficient counterbalancing measures are in place. This appeared to be the view of the court in Kok. ${ }^{67}$ That position was, however, rejected in $\mathrm{Al}$ Khawaja and Tahery v United Kingdom. ${ }^{68}$ Citing the relevant paragraph of Doorson, the court reiterated that:

Even when 'counterbalancing' procedures are found to compensate sufficiently the handicaps under which the defence labours, a conviction should not be based either solely or to a decisive extent on anonymous statements. ${ }^{69}$

The decision in Al-Khawaja and Tahery thus brought a welcome measure of clarity to a series of cases which did not sit particularly easily alongside each other. While the parameters of Article 6(3)(d) are not yet (and perhaps never will be) fully delineated, we now have a relatively concrete understanding of the appropriate threshold concerning the use of anonymous witnesses. In summary, while anonymous evidence per se does not contravene Article 6 of the Convention, it is clear that it should only be received in the most exceptional of circumstances as a measure of last resort. Even where a plethora of counterbalancing measures has been put place, the court has now made it clear that anonymous evidence still cannot be the sole or decisive basis for a conviction. This potentially carries significant ramifications for adversarial jurisdictions, insofar as the court would seem to require that trial judges adopt 'a more proactive and dominant role in the proceedings' in determining whether cross-examination is required for Article 6 rights to be fully protected. ${ }^{70}$

65 The lack of corroborative evidence appeared to be decisive in Kostovski $\mathrm{v}$ Netherlands (1989) 12 EHRR 434 at [44]; Windisch v Austria (1991) 13 EHRR 281 at [31]; and Ludi v Switzerland (1992) 15 EHRR 173 at [47].

66 (1996) 23 EHRR 330 at [69].

67 App. No. 43149/98, 4 July 2000. What is of greater interest about this case is, however, the court's statement immediately after reaching these conclusions: 'In the Court's view, in assessing whether the procedures involved in the questioning of the anonymous witness were sufficient to counterbalance the difficulties caused to the defence due weight must be given to the above conclusion that the anonymous testimony was not in any respect decisive for the conviction of the applicant. The defence was thus handicapped to a much lesser degree.' (Reports of Judgments and Decisions 2000-VI, p. 597.)

68 (2009) 49 EHRR 1.

69 Doorson v Netherlands (1996) 23 EHRR 330 at [76].

70 J. Jackson, 'The Effect of Human Rights on Criminal Evidentiary Processes: Towards Convergence, Divergence or Realignment' (2005) 68 MLR 737 at 756. 


\section{Witness anonymity in England and Wales}

\section{(a) Background}

The adversarial nature of the English common law system was well established from the days of the Royal Courts in the Middle Ages. The right of the accused to cross-examine witnesses would appear to have surfaced in the 16th century. ${ }^{71}$ Since then, the principle of orality has required that witnesses testify live, in open court, under oath. Apart from the notorious era of the Star Chamber, the English courts have historically shunned anonymous evidence. As Lord Bingham observed in Davis, $^{72}$

by a series of small steps, largely unobjectionable on their own facts, the courts have arrived at a position which is irreconcilable with long-standing principle. $^{73}$

These 'small steps' were achieved through the courts exercising their apparent common law powers to facilitate the giving of evidence by tweaking procedures. The first step of note was the Court of Appeal's decision in $R \mathrm{v}$ Watford Magistrates' Court, exp. Lenman. ${ }^{74}$ The prosecution applied for witnesses to give evidence anonymously behind screens following an incident of violent disorder. The application was granted, with Beldam LJ stating that it was 'well established' that anonymity could be offered where the interests of justice so required. As Lord Bingham noted in Davis, this was a curious statement in light of the fact that the only case supporting the proposition was that of $R \vee D J X, S C Y$, $G C Z{ }^{75}$ The circumstances there were quite different, with the defence already knowing the identity of the accusers. Screens were simply used to shield the child complainants from the sight of the accused; their identities were already known. Beldam LJ's reliance on that case as an authority for his proposition was highly dubious, and appears to mirror the above-noted tendency of the Strasbourg Court to conflate judicial reasoning to cover cases both where the identity of the witness is known, and those where it is not.

In its 1972 report, the Diplock Commission rejected the use of anonymous evidence in Northern Ireland as wholly inconsistent with the idea of a fair trial. ${ }^{76}$ This was despite a very real risk of reprisals where witnesses gave evidence in cases involving alleged terrorist-related offences. Such a view contrasted sharply with the report of the Royal Commission on Criminal Justice, which accepted that courts could allow witnesses to testify anonymously in exceptional circumstances. However, shortly afterwards the Court of Appeal upheld another anonymity ruling in $R \mathrm{v}$ Taylor ${ }^{77}$ Here, the witness in question was in a position to

71 See Seymour's Case, 1 How St Tr 483 (1549); Duke of Somerset's Trial, 1 How St Tr 515 (1551).

72 [2008] 1 AC 1128.

73 Ibid. at [29].

74 [1993] Crim LR 388.

75 (1990) 91 Cr App R 36.

76 See W. J. K. Diplock, Report of the Commission to Consider Legal Procedures to Deal with Terrorist Activities in Northern Ireland, Cmnd 5185 (HMSO: London, 1972) para. 20.

77 [1995] Crim LR 253. 
provide important corroborating evidence of the removal of the victim's body from a pub where it was alleged he had been killed. Again, citation of authority for allowing the anonymous evidence was somewhat thin; the court again relied on $D J X$ along with a handful of US authorities. It nonetheless dismissed the appeal, holding that anonymity orders were within the trial judge's discretion. The court then set out a list of relevant factors that should be taken into account before acceding to applications for anonymity: the question of the potential consequences of revealing the identity of the witness; the importance of the evidence he or she is providing; and no undue prejudice is caused to the defendant (although it was recognised that some degree of prejudice will be inevitable). In taking all of these factors into account, the court should balance the need for anonymity-including the consideration of other ways of providing witness protection in court (e.g. screening the witness or holding an in camera hearing or screen) against the unfairness or appearance of unfairness in the particular case. A number of cases followed, ${ }^{78}$ yet Taylor retained its status as the leading authority despite being somewhat ambiguous in terms of the specific circumstances where anonymity would be justifiable. As part of its wide-ranging review into the protection for vulnerable and intimidated witnesses, the Interdepartmental Working Group concluded that the present law was working 'satisfactorily' and saw no need to recommend reform. ${ }^{79}$

The issue of anonymity had not generally penetrated the headlines, until 18 June 2008, when it was propelled to the forefront of the national media in two distinct and opposing contexts. First, the government published a report, Engaging Communities in Fighting Crime, ${ }^{80}$ which called for the introduction of measures that would allow the elderly, the disabled and those who were fearful of reprisals to give evidence anonymously. On the same day, the House of Lords allowed an appeal of a convicted double-murderer $R$ v Davis and Others, ${ }^{81}$ on the grounds that seven prosecution witnesses had testified anonymously and three of those witnesses provided the only identification of the defendant as the gunman.

\section{(b) The decision in Davis}

The appellant, Davis, had been convicted by a jury of two counts of murder. The trial judge had allowed the evidence of the only identification witnesses to be given anonymously, having accepted that they, among others, were in genuine fear that if they gave evidence and their

78 See e.g. $R$ (on the application of DPP) v West London Youth Court [2005] EWHC 2834 (Admin); $R$ v Liverpool City Magistrates' Court, ex $p$. DPP (1997) $161 \mathrm{JP} 43 ; R$ (AlFawwaz) v Governor of Brixton Prison [2002] 1 AC 556; $R$ v Sellick [2005] 1 WLR 3257.

79 Interdepartmental Working Group on the treatment of vulnerable and intimidated witnesses in the criminal justice system, Speaking Up for Justice (Home Office: London, 1998) para. 8.32.

80 L. Casey, Engaging Communities in Fighting Crime (Ministry of Justice: London, 2008) 18.

81 [2008] 1 AC 1128 
identity was revealed their lives would be endangered. The order consisted of withholding the witnesses' names, addresses and identifying particulars from the defendant, preventing defence counsel from asking any question which might enable their identification, giving evidence under pseudonyms behind screens so that they could be seen by the judge and jury but not by the defendant, and mechanical distortion of the witnesses' natural voices, so although they could be heard by the judge and jury, recognition by the defendant was prevented (defence counsel voluntarily regarded himself as bound by those orders too). It was part of the defence case that the allegations may have been fabricated by a former girlfriend with whom the defendant had fallen out, an issue which counsel could not fully explore in cross-examination given his ignorance of who the witnesses were. It was accepted on subsequent appeal that the testimony of those witnesses was decisive.

The Court of Appeal dismissed Davis's appeal against conviction but the House of Lords unanimously agreed it should be allowed, and the case remitted to the Court of Appeal for consideration of a retrial. ${ }^{82}$ The reasoning of their Lordships was, however, far from clear. All agreed that on the facts that the anonymity orders were an unlawful constraint on the conduct of the defence and the defendant had not received a fair trial, but there was inconsistency in their Lordships' opinions as to the extent of the common law power to grant anonymity. Moreover, because the five speeches are largely free-standing, it is impossible to discern a specific ratio decidendi.

Lord Bingham regarded as paramount the common law principle that a defendant in a criminal trial should be able to confront his accusers so that he might cross-examine them and challenge their evidence. He was critical of previous decisions, including that of the Court of Appeal in the present case where such a fundamental principle was not awarded sufficient attention. ${ }^{83}$ He reviewed the recent authorities where anonymity orders had been granted and appeared to restrict each to its facts without overruling them. For example, anonymity had been permitted where the evidence did not implicate the defendant(s) in the crime and credibility was not in issue; ${ }^{84}$ where the evidence was admitted at committal proceedings rather than at trial; ${ }^{85}$ where the defendant had seen the witness by way of video camera while she was giving evidence; ${ }^{86}$ where anonymous affidavit evidence was admitted in respect of an extradition request; ${ }^{87}$ and where anonymous written statements had been admitted by a coroner conducting an inquest. ${ }^{88}$ His

82 The Court of Appeal later ordered a retrial without anonymising the relevant witnesses, but with other special measures directions to be determined by the judge (8 July 2008).

83 [2006] 1 WLR 3130.

$84 R$ v Murphy [1990] NI 306.

$85 R \mathrm{v}$ Watford Magistrates' Court, ex $p$. Lenman [1993] Crim LR 388 and $R \mathrm{v}$ Liverpool Magistrates' Court, ex p. DPP (1996) $161 \mathrm{JP} 43$.

$86 R$ v Taylor and Crabb [1995] Crim LR 253.

$87 R$ (Al-Fawwaz) v Governor of Brixton Prison [2002] 1 AC 556.

$88 R \mathrm{v}$ Attorney-General for Northern Ireland, ex p. Devine [1992] l WLR 262. 
Lordship was of the opinion that the common law did not afford a judge the power to grant protective measures to protect anonymity any further than in these exceptional circumstances.

Lords Rodger, Brown and Mance expressed agreement with Lord Bingham on this issue, but Lord Carswell, with whom Lord Brown explicitly disagreed on this point, thought that the common law had developed more flexibly to permit protective measures. At [59] he distilled certain propositions including, where it is necessary and justified, a power to grant anonymity. Lord Carswell was obviously more uneasy with the decision than their other Lordships and admitted feeling a great difficulty about the case, but on these facts even he was of the view that the measures granted went beyond what was permissible and he was not 'sufficiently sure' that the trial was fair. ${ }^{89}$ The only flexibility at common law which was accepted by Lord Mance was in 'exceptional circumstances' such as those in Murphy. ${ }^{90}$ It is of note that Lord Rodger found it unnecessary even to decide the rightness of that decision. ${ }^{91}$

Lord Mance's speech focused primarily on the Strasbourg judgments. Although he concluded that 'the Strasbourg Court does not set its face absolutely against the admission of anonymous evidence in all circumstances' ${ }^{\prime}{ }^{92}$ the evidence of the three anonymous witnesses in the present case was the sole or decisive basis for the defendant's conviction and accordingly the trial was unfair.

If we revisit the three fundamental safeguards referred to above and apply them to the facts of Davis, we are left with the following conclusions. The House of Lords was not asked to and did not rule on whether witness anonymity was 'strictly necessary' but the trial judge and Court of Appeal had investigated and accepted as genuine the witnesses' claims of being in fear for their lives had their identity been known. Crucially however, the evidence did form the sole or decisive basis for the conviction; and it would have been impossible to put in place sufficient counterbalancing measures for the defence to ensure a fair trial.

At no stage of the speeches were the witnesses' Article 2, 3, or 8 rights mentioned, which stands the decision in stark contrast to the earlier decision of Doorson, and the later decision of Mayers considered below. ${ }^{93}$

\section{(c) The government response}

In the immediate aftermath of the decision, the CPS warned that almost 600 cases could be affected by the ruling, and a $£ 6$ million trial at the old

92 Ibid. at [82].

93 See further Doak, above n. 12. 
Bailey was halted. ${ }^{94}$ The case triggered considerable debate in the popular press, with cries of how 'barmy Law Lords' had 'unleashed anarchy' $^{\prime},{ }^{95}$ or how the decision had caused 'chaos in the legal system'. ${ }^{96}$ The Justice Secretary, Jack Straw, moved quickly to inform Parliament that anonymous evidence was 'fundamental' to the successful prosecution of many serious crimes. The decision, he said, was due to a 'technical defect in the law', which the government intended to remedy. ${ }^{97}$ The Parliamentary Draftsman's Office was immediately shifted into overdrive; the decision in Davis was published on 18 June 2008 and by 21 July 2008 it had been reversed by legislation. ${ }^{98}$

The Criminal Evidence (Witness Anonymity) Act 2008 abolishes any common law rules relating to anonymity that would have survived the decision in Davis, but recognises that unless there are exceptional circumstances the defendant is entitled to know the identity of witnesses against him. Under s. 2, a court may make a witness anonymity order in such terms as it considers appropriate to ensure the identity of a witness is not disclosed. Section 2(2) provides that the orders which may be used to ensure a witness's anonymity include withholding the witness's name and other identifying details; the use of a pseudonym; an embargo on questions that might lead to his identification; the use of screens and voice modulation. The list is not exhaustive.

The Act addresses the three fundamental safeguards discussed above in the context of the Strasbourg case law: necessity is addressed twice, the sole/decisive test is a relevant consideration and an 'appropriate' warning should be given to provide an element of counterbalance. Section 4 provides that three conditions must be satisfied before a witness anonymity order can be made. In respect of necessity, Condition A provides that the measures must be necessary to protect the safety of the witness or another person or to prevent serious damage to property (s. $4(3)(\mathrm{a}))$, or prevent real harm to the public interest (s. 4(3)(b)), and Condition $\mathrm{C}$ provides that the order must be necessary in the interests of justice because it appears to the court that it is important the witness should testify, and the witness would not testify if the order were not made (s. 4(5)). Additionally, in respect of s. 4(3)(a), the court should have regard to any reasonable fear ${ }^{99}$ of the witness especially whether the witness or another person would suffer death or injury, or there would be serious damage to property, if the witness were identified (s. 4(6)). Condition B addresses the defendant's fair trial rights and one relevant consideration that directly impinges on a fair trial (although not

94 See 'Murder trial halted by ban on anonymity of witnesses', Evening Standard, 24 June; 'Court ruling hits police witnesses', The Independent, 8 July 2008.

95 'Anarchy is unleashed', The Sun, 25 June 2008.

96 Opinion, Daily Mirror, 25 June 2008.

97 Hansard, HC Deb, 26 June 2008, col. 516.

98 For an analysis of the speed of the enactment process, see D. Howarth, 'The Criminal Evidence (Witness Anonymity) Act 2008' [2008] 8 Archbold News 6.

99 That fear is not synonymous with safety is also examined by Howarth, above n. 98. 
of itself conclusive in respect of this condition) ${ }^{100}$ is whether the witness's evidence may be sole or decisive. Counterbalancing measures are implicit in the Act, including, for example, the judge's consideration of whether the witness's evidence could be properly tested if he were to be anonymous (s. 5(2)(d)) and whether it would be reasonably practicable to protect the witness's identity by means other than an anonymity order (s. 5(2)(f)). An explicit measure is found in s. 7 which provides that a judge must give the jury such warning as the judge considers appropriate to ensure that the fact that the order was made in relation to the witness does not prejudice the defendant. ${ }^{101}$ Indeed, it has been suggested that it may prejudice further the fair trial rights of the accused by inferring to the jury that the defendant is a dangerous individual from whom other witnesses need to be shielded. ${ }^{102}$ All in all, the provisions of the Act are not hugely different from the considerations that were held to be inadequate by the House of Lords in Davis.

\section{(d) The decision in Mayers}

The consolidated appeals of $R \mathrm{v}$ Mayers and Others ${ }^{103}$ were the Court of Appeal's first opportunity to examine the provisions of the Criminal Evidence (Witness Anonymity) Act 2008. The Lord Chief Justice stated expressly that the judge's role involves a 'delicate balance' between the defendant's fair trial rights under Article 6 of the European Convention on Human Rights and those of the witness under Articles 2 (life), 3 (physical security) and 8 (private life). ${ }^{104}$ The nature of this balance was not enunciated in the speeches of their Lordships in Davis which, as Professor Ashworth has pointed out, ${ }^{105}$ raises a point of contrast between the reasoning of the House in that case and $R \vee G^{106}$ and which, it is our contention, would have rendered the decision in Davis subject to far harsher criticism had it not been reversed by the Act.

In the first case, Mayers, the defendant appealed against his conviction for murder. By the end of the trial, it was clear that the only identification witness was the one witness who had been subject to an anonymity order. She had come to the attention of the prosecution very close to the trial and had an association with another man who had at one time been a suspect in the case. The Court of Appeal held that before an anonymity order for a civilian witness be granted, the judge should ensure there had been a full investigation into the character of the witness, his or her credibility, motive for giving evidence, possible association with the defendant (or defendants, or their families), of collusion with any other anonymous witness(es), as well as consequent disclosure of relevant

100 See $R$ v Mayers [2009] 1 Cr App R 30 at [19] and [23].

101 Note, however, that the Strasbourg Court's view in Al Khawaja and Tahery v United Kingdom (2009) 49 EHRR 1 that no warning to the jury could have served to compensate for the loss of opportunity of seeing and hearing the witnesses (at [28]).

102 Howarth, above n. 98 at 7.

103 [2009] l Cr App R 30.

104 Ibid. at [6].

105 Case Comment to $R$ v Davis [2008] Crim LR 915.

106 [2008] Crim LR 818. 
information. If a judge is dissatisfied with the investigation, disclosure or 'good faith of the efforts made ... into any relevant consideration bearing on the question of witness anonymity' an application should be met with a 'point blank refusal'. ${ }^{107}$ The Court of Appeal approved the decision in respect of public interest immunity in $R \mathrm{v} H$ and $C_{,}^{108}$ and encouraged a parallel adoption of Special Counsel into anonymity cases despite the fact that the Act is silent on the matter. ${ }^{109}$

Aside from whether the anonymity order was necessary under Conditions A and C, which the Court of Appeal did expressly consider, Mayers's appeal was allowed because his trial was not fair. The decisive nature of the witness's evidence and the 'absence of full and comprehensive inquiries' into her credibility, motivation and integrity rendered the conviction unsafe. ${ }^{110}$

Conversely, in the second appeal, Glasgow, there had been full investigations into the character and associations of the witnesses, all of which had been disclosed to the defence. Overlaying the three fundamental safeguards mentioned above to these facts leads to the conclusion that anonymity was necessary because the witnesses would not have testified had their identities been revealed (Condition $\mathrm{C}$ ) and they were in fear for their safety (Condition A), the evidence was not sole or decisive $^{111}$ and the existence of sufficient countermeasures ensured a fair trial. The issue at trial was the accuracy of the identification evidence on which the witnesses could be cross-examined. Witnesses were provided in the witness box with a list of the true names and pseudonyms of the other witnesses so they could comment on whether the other witness was present at the scene, and if so, where they were located. On the other hand, the defendant had not replied to police questions, had not made a defence statement and did not give evidence. The Court of Appeal emphasised the importance of defence disclosure as crucial, although that was not to understate the duty of the prosecution to be proactive. ${ }^{112}$ Further, the trial judge had addressed the possibility of relocating some or all of the witnesses, which he had rejected as ineffective, disruptive and/or disproportionate. On appeal, the court briefly discussed the availability of witness relocation orders in general, and concluded that they are rarely practicable alternatives to anonymity and would, if forced on a witness, engage his Article 8 rights. ${ }^{113}$

The third appeal, Costelloe and Bahmanzadeh, raised questions specific to the role of undercover police officers, where Condition A in respect of

107 [2009] 1 Cr App R 30 at [10].

108 [2004] 2 AC 134.

109 Attorney-General guidelines on the prosecutor's role in applications for witness anonymity are available on the Attorney-General's website: http:/ /www.attorneygeneral.gov.uk/sub_publications_guidelines.htm, accessed 13 October 2009. Part 4 deals with Special Counsel and restates the principles from $H$ and $C$.

110 [2009] 1 Cr App R 30 at [52].

111 Ibid. at [75].

112 Notwithstanding any diligence or good faith of the part of the investigating prosecutor, Lord Bingham in Davis was clear that '. . . the fairness of a trial should not depend on the diligent performance of their duties by prosecuting authorities': [2008] 1 AC 1128 at [31].

113 [2009] 1 Cr App R 30 at [9]. 
the public interest might be more easily met than for civilian witnesses (s. 4(3)(b)) and Condition C would be met because 'senior police officers would be likely to order [the officers] not to give evidence if their true identities were known'. ${ }^{114}$ The appellants had been convicted of offences in connection with the use of premises for the supply of Class A drugs after anonymity orders had been made in respect of undercover police officers, but defence counsel had nevertheless been able properly and fully to test the officers' evidence. The Court of Appeal held that 'there are often sound operational reasons' for maintaining the anonymity of undercover operatives and the court would normally be entitled to follow the unequivocal assertion by an undercover police officer that without an anonymity order he would not be prepared to testify ${ }^{\prime} .^{115}$ It is the contention here that such an approach may be acceptable in order to meet Conditions A and $\mathrm{C}$ where covert operations are involved, but if the defence is (in common parlance) entrapment and where the sole and/or decisive evidence against the defendant is that of an anonymous agent provocateur, a fair trial would be impossible. ${ }^{116}$

In the more recent decision of $R \mathrm{v}$ Powar, ${ }^{117}$ it was necessary for the witnesses to be granted anonymity where they genuinely and reasonably feared retaliation and they would not have given evidence if their identity had been known. Each witness was a neighbour of the accused and must have lived in one of 20 or so houses which overlooked the scene of the crime. The brutality of the murder, which had taken place in public, was also a relevant factor. The evidence was neither sole nor decisive, but nor was it consistent across all witnesses; something the defence had the opportunity to test, but this went to reliability rather than credibility. The accused had not reacted to the judge's invitation to identify by way of defence statement any trouble which any of them had with any of their neighbours. The defence submission on appeal that witness anonymity orders should be confined to cases of terrorism or 'gangland' killings was rejected. Of particular interest was the acknowledgment by the trial judge that witness anonymity orders were 'no longer rare', ${ }^{118}$ which would suggest that contemporary practice regularly falls well short of the Strasbourg threshold that anonymity should be a measure of last resort reserved for the most exceptional of circumstances.

\section{The Coroners and Justice Bill 2009}

The Criminal Evidence (Witness Anonymity) Act 2008 is subject to a sunset clause and, unless extended, will expire on 31 December 2009. ${ }^{119}$

114 Above n. 113 at [30].

115 Ibid.

116 The fourth case in the consolidated appeals was a prosecution application in respect of anonymous hearsay. Although of interest, there is not enough space to include a full analysis here. See further R. Huxley-Binns, Case in detail [2009] 1 Archbold News 6.

117 [2009] 2 Cr App R 8.

118 Ibid. at [42].

119 See David Howarth's description of practice in New Zealand, above n. 98. 
Part 3 of the Coroners and Justice Bill 2009, introduced to Parliament on 14 January 2009, will re-enact the central provisions of the 2008 Act, subject to some 'modifications' (in the words of the Explanatory Notes).

The provisions of the Bill broadly mirror the 2008 Act. As such, it might be viewed as a missed opportunity to frame the law in line with international standards and practices that are perceived to work relatively effectively elsewhere. No provision is made for the use of Special Counsel, ${ }^{120}$ and Professor Ormerod laments the failure of the government to consider devising special rules governing the making of anonymity orders for undercover state agents as opposed to civilian witnesses. ${ }^{121}$ Yet even before tinkering with the law, arguably policymakers should have afforded priority to bolstering the existing witness protection arrangements in England and Wales. As the human rights NGO Justice has suggested, the resort to witness anonymity is often a poor substitute for putting in place proper witness protection measures. ${ }^{122}$ If fearful witnesses were offered a more comprehensive level of protection at any early stage in the criminal investigation, then there is a greater likelihood that anonymity would be viewed by the courts as an exceptional measure and a last port of call where initial arrangements were likely to be insufficient. ${ }^{123}$

More significantly however, there remains some disquiet as to whether the provisions of the Bill are compatible with Convention standards. ${ }^{124}$ Foremost among these concerns are the grounds on which an anonymity order may be granted. Anonymity may not only be granted to ensure the safety of witnesses and their associates, but (pursuant to Condition A in cl. 84(3)) can also be ordered to 'prevent any serious damage to property' or to 'prevent real harm to the public interest'. The former ground appears to be unduly broad; cases before the European Court of Human Rights have invariably involved threats to human life or to the physical integrity to the person. Casting the net to capture incidences of criminal damage could potentially be used to allow anonymous witnesses to be readily introduced for a form of

120 See also Howarth, above n. 98.

121 Case comment to $R$ v Mayers [2009] Crim LR 272.

122 Justice, above n. 6 at para. 185.

123 Currently no centralised witness protection arrangements exist in England and Wales, with local police forces administering their own schemes and making decisions about which witnesses are eligible for protection. Part 2, Ch. 4 of the Serious Organised Crime and Police Act 2005 lays down various requirements for protecting witnesses and other persons who are involved in investigations or proceedings where the risk to their safety is so serious and life threatening that a change of identity and/or relocation is necessary. Clause 73 of the Coroners and Justice Bill 2009 makes provision for 'investigation anonymity orders' in cases of murder or manslaughter caused by a firearm or a knife. These prohibit the disclosure of any information that (a) identifies the specified person as a person who is or was able or willing to assist a qualifying criminal investigation specified in the order, or (b) that might enable the specified person to be identified as such a person. Clause numbers are correct as at 3 November 2009, but are subject to change.

124 Notwithstanding the view of the Justice Secretary who, pursuant to s. 19 of the Human Rights Act 1998, stated that in his view the measures in the Bill were compatible with Convention rights. 
relatively low-level crime. As the Equality and Human Rights Commission has recognised, this provision would appear to fall a long way short of the standard ordinarily required by the Strasbourg Court. ${ }^{125}$ In the same way, the latter ground, alluding to the protection of the public interest, carries its own dangers. The question as to what qualifies as the 'public interest' is fraught with difficulty, and there is a strong possibility that it could be used to protect a variety of state interests as opposed to merely protecting the identity of undercover officers.

One of the points of divergence between the anonymity arrangements under the Bill and those under the 2008 Act is the absence of the term 'necessary' as part of Condition C. Whilst s. 4(5)(a) of the 2008 Act explicitly made clear that the order had to be 'necessary' in the interests of justice because of the importance of the testimony and the fact that the witness would not testify if the order were not made, cl. 84(5) now provides that:

Condition $\mathrm{C}$ is that the importance of the witness's testimony is such that in the interests of justice the witness ought to testify and-

(a) the witness would not testify if the proposed order were not made, or

(b) there would be real harm to the public interest if the witness were to testify without the proposed order being made. (Emphasis added)

Thus not only has word 'necessary' been dropped, but it is also far from clear what the latter alternative requirement adds to the necessity requirement under the unamended Condition A. In Mayers, ${ }^{126}$ Lord Judge CJ directed that Condition $\mathrm{C}$ be addressed first. This was logical because if the witness was prepared to give evidence without an anonymity order, one would not have been necessary; and an unnecessary anonymity order would clearly breach Article 6. Under the Coroners and Justice Bill, however, necessity is not a requirement under Condition $\mathrm{C}$, and an anonymity order could be granted because otherwise there would be 'real harm to the public interest'. Condition A should therefore be considered first-the order is necessary to protect the witness's (or another's) safety, or prevent serious property damage or real harm to the public interest. The importance of the testimony (Condition C) should then be set off against the defendant's fair trial rights (Condition $\mathrm{B}$ and the unamended supplementary considerations now in cl. 84).

Far from reconciling English law with the Convention standard, it appears that the 2009 Bill dilutes the accused's Article 6 rights still further through broadening the grounds of which an anonymity order may be granted. Moreover, it can be noted that neither the 2008 Act nor the 2009 Bill encapsulate the core Convention requirement that convictions must not be solely or decisively based on anonymous testimony.

125 Equality and Human Rights Commission, Parliamentary Briefing: Coroners and Justice Bill House of Commons, Committee Stage (Equality and Human Rights Commission: London, 2009).

126 [2009] 1 Cr App R 30. 
Whilst the 'sole/decisive' question is laid down as a 'relevant consideration' for the court under cl. 85(2)(c), courts are not bound to refuse to issue an order in these circumstances. As such, the scheme clearly envisages the possibility of an accused being convicted solely or decisively on the basis of anonymous witness testimony.

\section{Conclusions}

Witness anonymity is a thorny issue, and care should be taken not to belittle those who suffer from, or fear, the very real problem of witness intimidation. The value of anonymity orders to such persons should not be underestimated and, likewise, they are an invaluable tool for enabling prosecutions to proceed in cases where they might not have otherwise done so. While searching for solutions to pressing new problems, it is right that policymakers should take heed of newly emergent rights for victims and witnesses, and be prepared to take innovative and even unpopular steps to assist such persons. Labyrinthine interest-balancing exercises are bound to arise from time to time, and the European Court of Human Rights still faces a tortuous task to clarify how specifically the rights of victims and witnesses under Articles 2, 3, and 8 of the Convention dovetail with the fair trial rights of the accused. ${ }^{127}$ Thus far, the court has been relatively imprecise in the guidance it has provided on the complexities inherent in such an exercise. However, in a climate of 'popular punitiveness', ${ }^{128}$ it is arguably all too easy for the government to couch reforms in the language of victims' rights, when more sinister state interests or political motivations may well dictate the direction of criminal justice reform. ${ }^{129}$ As such, we ought to be vigilant that rights that are well established in both the domestic legal system and the international platform are not lightly eroded.

There are certainly circumstances where anonymity can, and should, be granted without compromising the rights of the defence. A fair trial can still be ensured providing the court deems the order strictly necessary for the protection of life/physical integrity of an individual, puts in place sufficient countermeasures for the defence, and ensures that any conviction is not based solely or decisively upon such evidence. That would appear to be the (relatively clear) position of the European Court of Human Rights, but it is apparent that English law imposes a much lower threshold. It would seem that yet another nudge from Strasbourg may be required if domestic law is to become fully compliant.

127 See further Gillespie and Bettison, above n. 4; Doak, above n. 12; F. Klug, 'Human Rights and Victims' in E Cape (ed.), Reconcilable Rights? Analysing the Tension between Victims and Defendants (Legal Action Group: London, 2004); F. Leverick, 'What Has the ECHR Done for Victims?' (2004) 11 IRV 177.

128 A. Bottoms, 'The Philosophy and Politics of Punishment and Sentencing' in C. Clarkson and R. Morgan (eds), The Politics of Sentencing Reform (Clarendon Press: Oxford, 1995).

129 See further J. Jackson, 'Justice for All: Putting Victims at the Heart of Criminal Justice?’ (2003) 30 JLS 309. 